\title{
IGK Positive
}

National Cancer Institute

\section{Source}

National Cancer Institute. IGK Positive. NCI Thesaurus. Code C162101.

An indication that IGK expression has been detected in a sample. 